\title{
PENERAPAN PEMBELAJARAN BERBASIS MASALAH UNTUK MENINGKATKAN KEMAMPUAN BERPIKIR KRITIS DAN HASIL BELAJAR IPA SISWA MTsN 1 BANTUL
}

\author{
ASIH BUDIATI \\ MTs Negeri 1 Bantul \\ e-Mail : abudiati010@gmail.com
}

\begin{abstract}
ABSTRAK
Penelitian ini dilaksanakan untuk mengetahui pengaruh penerapan pembelajaran berbasis masalah untuk meningkatkan kemampuan berpikir kritis dan hasil belajar IPA siswa MTsN 1 Bantul. Penelitian ini berupa PTK yang dilaksanakan dalam dua siklus, dengan dua pertemuan pada setiap siklusnya. Setiap siklus terdiri empat tahap yaitu: perencanaan, pelaksanaan tindakan, pengamatan, dan refleksi. Subyek penelitian ini adalah siswa kelas VIIE MTsN 1 Bantul yang berjumlah 31 siswa. Waktu penelitian pada bulan Februari-April 2020. Metode pengumpulan data yang digunakan adalah observasi, dokumentasi, dan tes hasil belajar. Data yang diperoleh selama tindakan dianalisis menggunakan teknik analisis kualitatif dengan cara kategorisasi/penggolongan meliputi reduksi data, penyajian data dan pengambilan kesimpulan. Akhir penelitian diperoleh data bahwa penerapan pembelajaran berbasis masalah dapat meningkatkan kemampuan berpikir kritis hingga akhir siklus II mencapai jumlah melebihi atau sama dengan $76 \%$, yang meliputi mengidentifikasi masalah $83 \%$, menemukan penyebab peristiwa $81 \%$, menilai dampak peristiwa $81 \%$, memprediksikan dampak lanjut $76 \%$ dan merancang solusi menyelesaikan masalah $81 \%$. Untuk hasil belajar mengalami peningkatan yang berarti dari pembelajaran sebelum tindakan hingga akhir siklus II, yaitu nilai rata-rata meningkat 18 point dari nilai 63 menjadi 81, dan jumlah siswa yang mencapai KKM meningkat 18 anak dari 6 menjadi 24.
\end{abstract}

Kata Kunci : Pembelajaran Berbasis Masalah, Berpikir Kritis, Hasil Belajar

\section{PENDAHULUAN}

Pada era pembelajaran sekarang ini, diharapkan terjadi kolaborasi yang sinergis antara siswa, guru, dan lingkungan pembelajaran, serta didukung dengan IT yang semakin canggih untuk menuju tercapainya tujuan pendidikan. Belum semua guru siap dengan tuntutan sistem yang baru, tetapi setidak tidaknya guru diharapkan siap berubah dan selalu mengikuti perkembangan dalam bidang pendidikan secara aktif.

Guru sebagai garda terdepan dalam dunia pendidikan, harus sadar bahwa tugas tersebut bukanlah tugas yang ringan. Hitam putihnya dunia pendidikan sangat dipengaruhi oleh kesiapan guru untuk terlibat didalamnya. Guru yang mengajar dengan prinsip apa adanya, akan menghasilkan siswa yang berprestasi seadanya. Tetapi jika guru bersemangat untuk mewarnai dunia pendidikan dengan prestasi, maka akan dihasilkan siswa siswa yang berprestasi dalam berbagai macam prestasi. Siswapun juga mempunyai peran yang tidak kalah penting dalam memberi warna dunia pendidikan, kualitas belajar siswa akan memberi pengaruh terhadap kualitas hasil belajar siswa. 
Peran siswa yang masih rendah dalam pembelajaran sering ditemui dalam praktik pembelajaran IPA. Siswa masih banyak tergantung guru dan kurangnya budaya literasi, minimal membaca buku pokok yang dimiliki. Hal tersebut memberi andil yang besar terhadap keterbatasan hasil belajar siswa.

Masih adanya pembelajaran yang cenderung menghafalkan konsep-konsep berdampak rendahnya kemampuan aspek koknitif, yang hanya cenderung hafalan saja. Sedangkan domain yang lebih tinggi seperti berpikir kritis yang meliputi analisis, sintesis dan evaluasi belum terbiasa dilatihkan kepada siswa. Dari faktor siswa dalam belajar masih banyak yang selalu mengharapkan petunjuk guru untuk mempelajari sesuatu, belum menjadi pembiasaan untuk mencari solusi dari suatu permasalahan. Kegiatan diluar instruksi guru jarang dilakukan, sehingga wawasan siswa menjadi terbatas. Salah satu akibatnya adalah ketercapaian KKM masih sangat rendah. Hal tersebut ditunjukkan oleh perolehan hasil ulangan siswa pada mapel IPA, pada tabel berikut :

Tabel 1. Hasil Ulangan Sebelum Tindakan

\begin{tabular}{|cccc|}
\hline \multicolumn{4}{c|}{ Hasil ulangan harian IPA sebelum tindakan } \\
\hline Rata-rata & Nilai tertinggi & Nilai terendah & Jumlah tuntas KKM \\
\hline 6,34 & 85 & 5,6 & 6 \\
\hline
\end{tabular}

Dari data diatas menunjukkan bahwa dalam pembelajaran IPA masih diperlukan adanya kreasi dan inovasi dalam pembelajaran yang dapat membantu guru untuk mempermudah penyampaian materi serta meningkatkan pemahaman siswa terhadap materi yang dipelajari. Pelaksanaan penelitian tindakan kelas dapat menjadi alternatif positif untuk mengatasi masalah yang terjadi dalam pembelajaran. Suharsimi Arikunto (2010:17) menyampaikan bahwa penelitian tindakan kelas terlaksana dengan tahapan perencanaan, pelaksanaan, pengamatan, dan refleksi. Dengan tahapan dalam PTK tersebut, diharapkan setiap pembelajaran yang terjadi selalu terencana dan cenderung menggunakan media pendukung pembelajaran.

Pembelajaran IPA mencakup materi yang cukup luas, sehingga memungkinkan untuk melakukan variasi metode pembelajaran. Obyek IPA yang sangat banyak macamnya memberi peluang siswa untuk dapat bervariasi mencari contoh obyek pembelajaran, dari sampel sel tunggal sampai sel majemuk ataupun berbagai hewan dan tumbuhan. Oleh karena itu tidak selayaknya kalau pembelajaran IPA bersifat teacher centered learning tetapi sudah harus student centered learning, karena pendekatan pembelajaran yang tepat akan memberi hasil belajar yang baik, serta meningkatkan pola pikir siswa. Pembelajaran yang melibatkan langsung peranan siswa dalam membahas dan mendalami materi sangat diharapkan dapat diterapkan dalam setiap pembelajaran IPA, dalam rangka menanamkan rasa keingintahuan dalam berbagai hal, serta mengurangi atau menghilangkan kebiasaan tergantung pada guru. Kondisi siswa yang cenderung menerima materi pembelajaran sebatas informasi guru masih banyak dijumpai dalam KBM IPA, sehingga perlu adanya usaha peningkatan kemampuan berpikir kritis siswa dalam mempelajari materi pembelajaran.

IPA adalah ilmu yang mempelajari alam semesta, yang berarti baik benda mati ataupun hidup di dalamnya. Pelajaran IPA sering dianggap sebagai pelajaran yang 
sulit bagi sebagian besar siswa, karena banyak materi atau masalah lain yang ada di dalamnya. Teknik sains merupakan ciri khas yang dapat dijadikan identitas IPA dari metodologinya. Sekarang ini pruduk IPA sangatlah banyak, hal ini menunjukkan begitu pesatnya perkembangan IPA dalam dunia pendidikan maupun teknologi terapan. Tentu kita tidak dapat menganalisa satu demi satu produk tersebut, tetapi kita ketahui semua produk IPA tentu terkait dengan keberadaan alam semesta dan faktor lain didalamnya. IPA bersifat analisis, IPA mengamati sesuatu secara lengkap dan cermat, serta dihubungkan dengan obyek lain sehingga secara keseluruhan membentuk perspektif baru tentang obyek yang diamati tersebut. Jadi IPA dipandang sebagai suatu cara atau metode atau suatu pola berpikir terhadap sasaran dengan seksama dan lengkap.

Materi IPA klas VII sangat kompleks, karena terdiri dari materi biologi, fisika maupun kimia. Materi-materi tersebut ada yang berdiri sendiri dengan ciri khas masing masing ataupun berada dalam satu materi terpadu. Pada penelitian ini difokuskan pada materi pertambahan penduduk dan akibatnya pada lingkungan. Materi ini merupakan salah satu materi terpadu dari materi biologi, fisika dan kimia. Siswa mempelajari bagaimana pertumbuhan penduduk terjadi , bagaimana lingkungan biologis mendapat pengaruhnya, serta berbagai perubahan fisik yang terjadi pada lingkungan, baik melalui perubahan secara biologis maupun kimiawi. Secara garis besar materi ini mempelajari tentang kondisi semakin pesatnya pertambahan penduduk serta hal hal yang menjadi akibat dari pertambahan penduduk tersebut. Materi pembelajaran ini sangat dekat dengan keseharian siswa, dengan harapan siswa dapat lebih mudah memahami masalah yang disajikan sehingga membantu siswa menguasai materi yang dipelajari. Berbagai masalah lingkungan yang dapat disebabkan oleh pertumbuhan penduduk yang cepat antara lain terjadinya lingkungan yang tidak seimbang atau terjadi berbagai pencemaran, diantaranya pencemaran tanah, air dan udara.

Dari kondisi diatas, salah satu metode pembelajaran yang diharapkan dapat membantu peningkatkan hasil belajar dan menimbulkan pola berpikir kritis siswa adalah Pembelajaran Bermasis Masalah (PBM). Dalam pembelajaran dengan PBM ini siswa dihadapkan pada suatu masalah di awal pembelajaran sebagai tantangan pada proses pembelajaran yang berlangsung. Masalah tertentu digunakan untuk menumbuhkan rasa keingintahuan serta kemampuan analitik dan inisiatif siswa atas materi yang dipelajari. Kemudian siswa diajak untuk mencari solusi penyelesaian masalah yang ada. Diharapkan dengan PBM siswa dapat berpartisipasi aktif dalam pembelajaran.

Pembelajaran Berbasis Masalah ( PBM ) dalam penelitian ini didefinisikan sebagai suatu model pembelajaran yang menggunakan masalah nyata (masalah yang ada dalam kehidupan sehari-hari) sebagai konteks bagi siswa untuk belajar tentang cara berpikir kritis, pemecahan masalah, serta untuk memperoleh pengetahuan yang esensial. Menurut Arends (2008:57), ada lima tahap yang perlu dilakukan untuk mengimplementasikan PBM, yaitu : mengoreantasikan siswa pada masalah, mengorganisasikan siswa untuk belajar, membimbing penyelidikan individu atau kelompok, mengembangkan hasil karya, dan menganalisis serta mengevaluasi proses pemecahan masalah . 
Pembelajaran berbasis masalah merupakan pembelajaran yang menggunakan kondisi nyata berbagai sumber permasalahan yang perlu dicari solusinya , memberikan berbagai pertanyaan pengarah, dan memfasilitasi investigasi serta diskusi. PBM tidak dirancang untuk membantu guru menyampaikan informasi materi pelajaran dalam jumlah besar kepada siswa, tetapi mengembangkan ketrampilan berpikir, ketrampilan menyelesaikan masalah, dan ketrampilan intelektualnya, Arends (2008:43).

Guru menerapkan pembelajaran berbasis masalah untuk meningkatkan keterlibatan siswa secara aktif, oreantasi yang induktif, dan penemuan atau pengkonstruksian pengetahuan oleh siswa sendiri. Selain itu model pembelajaran berbasis masalah juga ditandai dengan siswa yang bekerja berpasangan dalam kelompok-kelompok kecil untuk menginvestigasi masalah kehidupan nyata yang sangat banyak (Arends, 2008:51). Wina Sanjaya (2009: 214) mengemukaan ada tiga hal utama dalam model pembelajaran berdasarkan masalah, yaitu merupakan rangkaian aktivitas pembelajaran, beroreantasi dalam menyelesaikan masalah, penyelesaian masalah melalui pendekatan berpikir ilmiah.

Para pengembang PBM mendiskripsikan bahwa model instruksional ini memiliki unsur-unsur ,Arends ( 2008 : 42-43) mempunyai masalah perangsang, bersifat fokus interdisipliner, bersifat investasi autentik, produk investasi dalam bentuk artefak atau exhibit, dan bersifat kolaboratif.

Tabel 2. Sintaks PBM Menurut Arends

\begin{tabular}{|c|c|}
\hline Tahap & Perilaku Guru/ siswa \\
\hline $\begin{array}{l}\text { Tahap } 1 \\
\text { Memberikan orientasi } \\
\text { tentang permasalahan kepada } \\
\text { siswa }\end{array}$ & $\begin{array}{l}\text { Diawal kegiatan pembelajaran guru } \\
\text { menyampaikan tujuan, mendiskripsikan } \\
\text { berbagai kebutuhan logistik penting dan } \\
\text { memotivasi siswa dapat aktif dalam } \\
\text { kegiatan mengatasi masalah }\end{array}$ \\
\hline $\begin{array}{l}\text { Tahap } 2 \\
\text { Mengorganisasikan } \\
\text { untuk meneliti }\end{array}$ & $\begin{array}{l}\text { Kegiatan dilanjutkan dengan } \\
\text { mendefinisikan dan mengorganisasikan } \\
\text { tugas-tugas belajar yang berkaitan dengan } \\
\text { permasalahan. }\end{array}$ \\
\hline $\begin{array}{l}\text { Tahap } 3 \\
\text { Membantu investigasi } \\
\text { mandiri dan kelompok }\end{array}$ & $\begin{array}{l}\text { Siswa didorong untuk mendapatkan } \\
\text { informasi yang tepat, melaksanakan } \\
\text { eksperimen dan mencari penjelasan dan } \\
\text { solusi }\end{array}$ \\
\hline Tahap 4 & $\begin{array}{l}\text { Dengan pendampingan guru siswa } \\
\text { merencanakan dan menyiapkan artefak- } \\
\text { artefak yang disusun seperti laporan, }\end{array}$ \\
\hline
\end{tabular}




\begin{tabular}{|lll|}
\hline $\begin{array}{l}\text { Mengembangkan } \\
\text { mempresentasikan } \\
\text { dan exhibit }\end{array}$ & $\begin{array}{r}\text { dan } \\
\text { artefak }\end{array}$ & $\begin{array}{l}\text { rekaman video serta mempersiapkan untuk } \\
\text { dipresentasikan }\end{array}$ \\
\hline Tahap 5 & & $\begin{array}{l}\text { Siswa melakukan refleksi terhadap } \\
\text { investigasinya dan proses yang mereka } \\
\text { gunakan dalam menyelesaikan masalah }\end{array}$ \\
$\begin{array}{l}\text { Menganalisis } \\
\text { mengevaluasi } \\
\text { mengatasi masalah }\end{array}$ & proses & \\
\hline
\end{tabular}

Dari uraian tersebut diketahui bahwa keterlibatan siswa untuk turut belajar dengan cara menerapkan model pembelajaran PBM merupakan salah satu indikator keefektifan belajar. Siswa tidak hanya saja menerima materi dari guru, melainkan siswa berusaha menggali dan mengembangkan sendiri, serta siswa dituntut untuk dapat berpikir kritis dalam penyelesaian masalah yang ada. Hal tersebut dibuktikan dengan menyusun atau membuat keputusan yang tepat. Hasil belajar tidak hanya peningkatan pengetahuan tetapi juga kemampuan berpikir kritis. Dengan demikian diharapkan model pembelajaran berbasis masalah dapat melatih siswa belajar kreatif, disiplin, dan meningkatkan kemampuan berpikir kritis.

Daniel Dike (2008:16) menyampaikan bahwa kemampuan berpikir kritis merupakan ide yang dipromosikan oleh para filsuf dan psikolog aliran kognitif dan behavioristik. Berpikir kritis merupakan kemampuan untuk menganalisis berbagai kenyataan, membuat generalisasi, mengorganisasikan dan mempertahankan ide-ide, membuat komparasi, menilai argumen-argumen, membuat kesimpulan, dan memecahkan masalah.

Bowell \& Kemp (2002:6) berpendapat bahwa berpikir kritis meliputi tiga aspek, yaitu mengidentifikasi hal penting yang sedang dibahas, merekonstruksi argumen atau alasan, dan mengevaluasi argumen yang dikonstruksi untuk dapat membantu menyusun solusi masalah yang sedang dibahas. Berpikir kritis ditunjukkan dengan kemampuan siswa berpendapat, mengidentifikasi kesimpulan dan pendapat, serta menggabungkan kesimpulan. Indikator berpikir kritis meliputi kemampuan mengidentifikasi masalah, menemukan penyebab peristiwa, menilai dampak peristiwa, memprediksikan dampak lanjut, dan merancang solusi penyelesaian masalah. Indikator penilaian terhadap kemampuan berpikir kritis antara lain: untuk kemampuan mengidentifikasi masalah adalah siswa mampu merumuskan masalah utama dari permasalahan yang dihadapi dengan jelas. Untuk mengukur kemampuan mengidentifikasi penyebab peristiwa adalah siswa mampu merumuskan kejadian peristiwa yang disertai dengan penjelasan yang relevan dengan wacana yang diberikan. Untuk mengukur kemampuan menilai dampak peritiwa adalah siswa mampu mendiskripsikan minimal 3 dampak negatif dari peristiwa yang disajikan. Untuk mengukur kemampuan siswa memprediksikan dampak lanjut adalah siswa mampu membuat prediksi kejadian sesuai dengan alasan dalam wacana dan permasalahan yang 
telah dirumuskan sebelumnya. Sedangkan untuk mengukur kemampuan merancang solusi penyelesaian masalah adalah siswa mampu merumuskan solusi penyelesaian masalah dari yang sederhana hingga yang kompleks sesuai masalah yang ada.

Dalam kegiatan pembelajaran terjadi proses belajar dengan hasilnya adalah nilai atau hasil belajar. Proses belajar adalah kegiatan yang dilakukan oleh siswa dalam mencari tujuan pengajaran, sedangkan hasil belajar adalah kemampuan-kemampuan yang dimiliki siswa setelah ia menerima pengalaman belajar, Nana Sudjana ( 2009 : 22). Kemampuan belajar yang berupa hasil belajar intelektual, dibedakan menjadi empat, yaitu : faktual knowledge (pengetahuan factual), conceptual knowledge (pengetahuan konseptual), procedural knowledge (pengetahuan procedural), dan metacognitive knowledge (pengetahuan metakognitif). Nana Sudjana (2009:22) menyampaikan bahwa ranah kemampuan yang terukur meliputi : remember (mengingat), understand (memahami), apply (menerapkan), analyze (menganalisis), evaluate (mengevaluasi), create (menciptakan).

Hasil belajar yang banyak diterima siswa adalah hasil belajar dari kemampuan koknitif, meskipun juga terdapat beberapa bagian berupa penilaian afektif dan psikomotorik. Salah satu teknik yang digunakan untuk mendapatkan hasil belajar kognitif adalah melalui pelaksanaan tes, baik tes lisan maupun tertulis.

\section{METODE PENELITIAN}

Penelitian tindakan kelas ini bersifat reflektif yaitu melakukan tindakantindakan tertentu, untuk dapat memperbaiki dan meningkatkan praktek-praktek pembelajaran di kelas, sehingga mampu memotivasi semangat belajar dan dapat meningkatkan kemampuan berpikir kritis dan hasil belajar siswa. Penelitian yang relevan antara lain penelitian yang dilakukan oleh Endah Puji Novisetyani yang mendapatkan hasil bahwa pembelajaran berbasis masalah dapat meningkatkan kemampuan berpikir kritis siswa sebesar 68,75 \%. Begitu juga dengan penelitian Wiwit Trisnaningsih, yang memberi hasil bahwa pembelajaran berbasis masalah dapat meningkatkan kemampuan berpikir ktitis siswa sebesar 82,35\%.

Rancangan penelitian tindakan kelas ini dilaksanakan sesuai tahap tahap yang disarankan yaitu perencanaan, tindakan dan pengamatan serta refleksi. Penelitian dilaksanakan di MTs Negeri 1 Bantul, yang beralamat di jalan Imogiri Barat Km 4,5 Bangunharjo Sewon Bantul, pada bulan Februari - April 2020. Subyek penelitian adalah siswa kelas VII E yang berjumlah 31. Dengan materi yang dibahas adalah pertambahan penduduk dan efek samping yang diakibatkan.

Pada tahap perencanaan mempersiapkan perlengkapan administrasi yang diperlukan yaitu, RPP 4 pertemuan, soal pretest dan postest siklus I dan II, serta lembar observasi . Tahap observasi merupakan tahap pengamatan terhadap pelaksanaan dari semua rencana yang dibuat dalam RPP. Penelitian direncanakan dilaksanakan dua siklus, tiap siklus dua pertemuan, masing masing 2 dan 3 jam pelajaran. Pada pertemuan pertama melakukan tiga langkah awal PBM yaitu orientasi masalah, pengorganisasian masalah oleh siswa, dan pembimbingan investigasi siswa. Pada pertemuan kedua merupakan kelanjutan dari pertemuan pertama yaitu menerapkan langkah selanjutnya dari PBM yakni menyajikan hasil diskusi dengan presentasi , analisis, dan evaluasi proses mengatasi masalah dan pelaksanaan postest. Pada awal 
pertemuan pertama setelah guru menyampaikan rencana materi yang hendak dipelajari sesuai dalam RPP, kemudian guru memberikan pretest sebagai data kemampuan awal siswa. Sedangkan pada akhir siklus atau akhir pertemuan kedua guru memberikan posttest sebagai data hasil belajar. Setelah pelaksanaan siklus pertama guru melaksanakan tahap berikutnya berupa tahap analisis dan refleksi. Hal yang dibahas selama refleksi diantaranya kesesuaian pelaksanaan tindakan dengan rencana, hambatan atau masalah selama tindakan, solusi untuk permasalahan yang ada. Dengan solusi tersebut disusun kembali rencana kegiatan untuk siklus II.

Instrumen untuk pengumpulan data penelitian berupa soal pretest dan postest, lembar observasi selama KBM, lembar observasi berpikir kritis yang berisi lembar kegiatan siswa. Teknik pengumpulan data yang dilakukan adalah melakukan analisa kualitatif terhadap data yang diperoleh selama observasi. Hasil postest pada akhir siklus sebagai data hasil belajar siswa, dan data observasi sebagai data kemampuan berpikir kritis siswa. Dalam pengolahan data kemampuan berpikir kritis digunakan persamaan : NP $=\mathrm{R} / \mathrm{SM} \times 100 \%$, dengan $\mathrm{NP}=$ nilai persentase yang diharapkan, $\mathrm{R}$ $=$ skor mentah yang diperoleh, $\mathrm{SM}=$ skor maksimum dengan kriteria $\leq 54 \%=$ kurang sekali, $55-59 \%=$ kurang, $60-75 \%=$ cukup, $76-85 \%=$ baik, $86-100 \%=$ sangat baik. Untuk penskoran hasil pretest dan postest dengan menggunakan persamaan :

$$
\overline{\boldsymbol{x}}=\frac{\sum \mathbf{y}}{\boldsymbol{n}} \boldsymbol{d i} \quad \overline{\boldsymbol{x}}=\text { rata-rata, } \sum \mathbf{y}=\text { jumlah semua skor, } \boldsymbol{n}=\text { jumlah }
$$

siswa. Indikator pencapaian keberhasilan dalam penelitian ini adalah peningkatan kemampuan berpikir kritis siswa untuk seluruh aspek lebih besar atau sama dengan 76 $\%$ pada akhir tindakan. Untuk indikator keberhasilan hasil belajar ditunjukkan telah $70 \%$ lebih siswa mencapai KKM diakhir tindakan.

\section{HASIL DAN PEMBAHASAN}

Siklus I berlangsung selama 5 jam pelajaran atau dua kali pertemuan, pada pertemuan pertama dilaksanakan tanggal 5 Maret 2020 selama 2 jam pelajaran . Guru membuka kelas dengan salam dan memberi apersepsi terkait dengan materi yang akan dipelajari hari itu. Kemudian guru mengawali tahap pertama model pembelajaran berbasis masalah yaitu dengan memberikan beberapa pertanyaan terkait dengan permasalahan yang akan dibahas berupa pertambahan penduduk dan penyebab terjadinya pencemaran lingkungan. Tidak semua siswa dapat merespon pertanyaan tersebut, hanya beberapa yang telah membaca ringkasan materi atau buku paket yang dapat memberi argumentasi atau tanggapan sepemahaman mereka. Kemudian guru memberi pretest untuk mengetahui sejauh mana kasiapan para siswa dalam mengikuti pelajaran . Hasil pretest akan dibandingkan dengan hasil posttest untuk mengetahui keberhasilan siklus I. Setelah kegiatan pretest guru menyampaikan tujuan pembelajaran hari itu.

Kemudian guru meminta siswa berkelompok sesuai kelompok yang telah dibentuk guru. Guru membagikan lembar kegiatan siswa yang berisi bacaan dan poster terkait pertambahan penduduk di Indonesia yang ada kecenderungan bertambah dengan pesat, serta beberapa soal yang harus diselesaikan siswa. Semua permasalahan dalam lembar kerja siswa diharapkan dapat diselesaikan siswa baik secara individu maupun dikerjakan bersama dengan berdiskusi dalam kelompoknya. Karena 
terbatasnya waktu, maka setiap siswa dapat menyelesaikan tugas dalam lembar kegiatan siswa tersebut di rumah.

Pertemuan kedua, dilaksanakan pada tanggal 6 Maret 2020 selama 3 jam pelajaran, guru memulai pelajaran dengan memberi resume tentang materi pada pertemuan pertama, kemudian guru menanyakan tugas yang harusnya diselesaikan di rumah. Namun tidak semua kelompok siap dengan tugasnya, hanya ada beberapa kelompok yang siap dengan tugas pertemuan pertama. Kemudian guru meminta kelompok yang telah siap untuk mempresentasikan hasil diskusinya. Setelah beberapa kelompok selesai presentasi kegiatan dilanjutkan dengan sesi tanya jawab. Kegiatan tanya jawab dilakukan secara terbuka terkait dengan materi pertambahan penduduk dan pencemaran air. Pertanyaan biasanya ditujukan kepada guru tetapi oleh guru pertanyaan tersebut diperjelas dan dilembarkan kesemua siswa, dan siswalah yang diharapkan dapat menjawab. Dalam kegiatan tanya jawab siklus I belum optimal karena hanya ada beberapa pertanyaan yang disampaikan dan kemampuan menjawabpun masih sangat terbatas. Kemudian guru memberikan penguatan dan penjelasan tambahan terkait dengan pertanyaan yang ada. Pertemuan diakhiri dengan postest.

Tabel 3. Data Hasil Observasi Kemampuan Berpikir Kritis Siswa Siklus I

\begin{tabular}{|llcc|}
\hline No & Kemampuan berpikir kritis & Rata-rata & Persentase \\
\hline 1 & Mengidentifikasi masalah & 1,6 & $53 \%$ \\
\hline 2 & Menemukan penyebab peristiwa & 1,9 & $63 \%$ \\
\hline 3 & Menilai dampak peristiwa & 2,0 & $67 \%$ \\
\hline 4 & Memprediksikan dampak lanjut & 1,5 & $50 \%$ \\
\hline 5 & Merancang solusi menyelesaikan masalah & 1,9 & $63 \%$ \\
\hline
\end{tabular}

Berdasarkan tabel 3 diketahui bahwa persentase hasil kemampuan berpikir kritis siswa tertinggi $67 \%$ pada aspek menilai dampak peristiwa sedangkan aspek dengan persentase terendah adalah memprediksikan dampak lanjut sebesar $50 \%$. Pada siklus I ini masih banyak siswa yang belum dapat mengikuti pembelajaran berbasis masalah dengan benar, masih banyak pembiasaan lama yang dilakukan seperti membaca menunggu perintah guru, jenis materi yang baca terbatas pada instruksi guru, sehingga hasil pengamatan terhadap berpikir kritis siswa masih belum memenuhi indikator keberhasilan penelitian.

Hasil pretest dan posttest merupakan data hasil belajar siswa selama pembelajaran berlangsung. Pada siklus I materi tes awal dan akhir siklus terkait dengan materi pertambahan penduduk dengan berbagai faktor yang mempengaruhinya serta terjadinya pencemaran air yang secara langsung maupun tidak langsung efek dari pertambahan penduduk yang sangat pesat atau tidak terkendali. 
Tabel 4. Data Hasil Belajar Siswa pada Siklus 1

\begin{tabular}{|lcc|}
\hline \multicolumn{1}{|c}{ Jenis test } & Pretest & Postest \\
\hline Nilai tertinggi & 80 & 85 \\
\hline Nilai terendah & 60 & 62 \\
\hline Rata-rata & 67 & 76 \\
\hline Jumlah siswa yang mencapai KKM & 5 & 14 \\
\hline
\end{tabular}

Dari tabel 4 diatas dapat diketahui bahwa jumlah siswa yang mendapatkan nilai mencapai KKM adalah 45\%, nilai ini cukup bagus karena peningkatan dari jumlah siswa yang mencapai KKM diawal siklus sampai akhir siklus sangat signifikan yaitu 9 siswa.

Pembahasan umum pada siklus 1 pertemuan pertama kegiatan guru dalam memberi informasi sangat terbatas, masih tampak kekurang seriusan siswa meskipun sudah ada perubahan dari segi sikap memperhatikan penjelasan guru. Keterlibatan siswa pada pembelajaran sebelumnya sangat kurang, pada saat dilakukan pembelajaran siklus I hasil observasi menunjukkan bahwa sebagian siswa telah mencoba aktif terlibat langsung dalam pembelajaran, baik berupa mencari penyelesaiaan masalah yang disampaikan guru maupun aktif berdiskusi dalam kelompoknya. Pada akhir siklus I siswa sebagian telah mampu melakukan langkah-langkah pembelajaran sesuai dengan PBM. Langkah tersebut adalah 1) menjawab apersepsi, memperhatikan penjelasan guru, 2) pembagian kelompok oleh guru, dengan mempertimbangkan keaktifan dan kemampuan siswa sebelum tindakan, 3) mempresentasikan hasil kelompok siswa, 4) siswa memperhatikan informasi dari guru terkait klarifikasi materi atau penguasaan materi yang dipelajari. Siswa tampak antusias dan bersemangat, yang menandakan kalau lebih paham. Beberapa hal yang masih menjadi kendala pelaksanaan pembelajaran berbasis masalah pada siklus I, baik dari siswa maupun guru atau sarana pembelajaran dibahas lebih rinci dalam refleksi untuk dapat disusun rencana kegiatan siklus II.

Berdasarkan hasil refleksi pada akhir siklus I antara lain 1) di awal pelajaran banyak siswa malas-malas saat guru memberi materi dan soal, baik soal pretest maupun soal dalam LKS tanpa guru menjelaskan terlebih dahulu, 2) pada saat diskusi siswa masih kurang aktif. Dua hal tersebut dimungkinkan karena siswa belum paham betul tahap tahap pembelajaran berbasis masalah, sehingga mereka belum mempersiapkan materi yang hendak dipelajari dalam pembelajaran dengan baik. Maka solusinya adalah guru memberi penjelasan kembali langkah langkah atau tahap tahap pembelajaran berbasis masalah, hal tersebut dilaksanakan diluar siklus. Beberapa rekomendasi untuk pelaksanaan siklus II antara lain 1) agar materi tampak lebih menarik maka materi yang disampaikan dalam LKS dapat ditambah dengan gambar 
gambar atau penjelasan tambahan, 2) guru memotifasi siswa sebelum diskusi bahwa kondisi masing masing anggota punya kelebihan dan kekuragan. Guru telah memperhatikan hal tersebut saat membagi kelompok,3) memberikan reward untuk peserta didik yang aktif dalam pembelajaran, serta yang mendapatkan hasil belajar paling tinggi.

Siklus II berlangsung selama 5 jam pelajaran atau dua kali pertemuan, pada pertemuan pertama dilaksanakan pada tanggal 12 Maret 2020 dengan 2 jam pelajaran. Guru memberikan menyampaikan apersepsi dengan memberikan beberapa pertanyaan terkait materi yang akan dipelajari dan siswa merespon pertanyaan tersebut, beberapa siswa yang telah membaca ringkasan materi atau buku paket dapat memberi argumentasi atau tanggapan sepemahaman mereka, beberapa jawaban yang ada bersifat saling melengkapi. Kemudian guru memberi pretest untuk mengetahui sejauh mana kasiapan para siswa dalam mengikuti pelajaran .

Kemudian guru meminta siswa berkelompok sesuai kelompok baru yang telah dibentuk guru sesuai hasil refleksi siklus I. Kegiatan dilanjut dengan tahapan berikutnya yaitu penyampaian lembar materi berupa narasi dan poster terkait pencemaran tanah dan pencemaran udara yang disampaikan pada semua kelompok. Dengan mempelajari materi siswa diminta menyusun permasalahan dengan dasar beberapa hal yang dapat dipelajari dari narasi dan poster yang disajikan sebelumnya. Pada tahap ketiga siswa diharapkan dapat menyelesaikan soal atau masalah yang ada dalam lembar kegiatan siswa baik secara mandiri atau dilakukan dengan berdiskusi bersama kelompoknya. Seperti pada siklus I untuk lebih mendapatkan jawaban yang lebih luas dan lengkap siswa dapat menyelesaikan tugas yang dalam lember kegiatan siswa tersebut di rumah.

Pada pertemuan kedua siklus II dilaksanakan pada tanggal 13 Maret 2020, dengan 3 jam pelajaran. Pada pertemuan terakhir ini hampir semua kelompok siap dengan tugasnya, mereka sudah terbiasa dengan pembelajaran berbasis masalah pada dua pertemuan sebelumnya. Setelah semua siswa mempersiapkan materi dan tugas pertemuan sebelumnya, guru meminta setiap kelompok mempresentasikan hasil diskusinya, kegiatan diskusi lebih hidup, banyak siswa yang ingin menyampaikan pendapat pendukung disaat teman sekelompoknya presentasi. Kegiatan berikutnya adalah tanya jawab seputar materi yang dipelajari yaitu pencemaran tanah dan pencemaran udara. Kegiatan ini cukup optimal karena banyak pertanyaan yang disampaikan siswa serta siswa telah mampu menjawab dengan jawaban yang lebih berkualitas. Diakhir pertemuan sebelum pelaksanaan tes akhir siklus guru memberikan penguatan materi, menyampaikan materi materi penting serta membenarkan konsep konsep yang kurang tepat saat diskusi kelas. Siswa mendengarkan dan mencatat beberapa informasi penting dari guru. Sebagai kegiatan terakhir pada siklus II guru memberikan soal posttest untuk dikerjakan. Hasil postest menjadi data perkembangan hasil belajar siswa dengan penerapan pembelajaran berbasis masalah, dengan materi pertambahan penduduk dan permasalahan yang dikibatkannya terhadap lingkungan. 
Tabel 5 : Hasil Observasi Kemampuan Berpikir Kritis Siswa pada Siklus II

\begin{tabular}{|llcc|}
\hline No & Kemampuan berpikir kritis & Rata-rata & Persentase \\
\hline 1 & Mengidentifikasi masalah & 2,5 & $83 \%$ \\
\hline 2 & $\begin{array}{l}\text { Menemukan sebab-sebab kejadian } \\
\text { peristiwa }\end{array}$ & 2,4 & $81 \%$ \\
\hline 3 & Menilai dampak dari kejadian peristiwa & 2,5 & $83 \%$ \\
\hline 4 & Memprediksikan dampak lanjut & 2,3 & $81 \%$ \\
\hline 5 & Merancang solusi berdasarkan masalah & 2,4 & \\
\hline
\end{tabular}

Berdasarkan tabel 5 diketahui bahwa persentase hasil kemampuan berpikir kritis siswa tertinggi $83 \%$ pada aspek menilai dampak dari kejadian peristiwa sedangkan aspek dengan presentase terendah adalah mengidentifikasi masalah sebesar $76 \%$. Data tersebut telah menunjukkan bahwa kegiatan pembelajaran dengan model pembelajaran berbasis masalah dapat mengoptimalkan keterlibatan siswa dalam pembelajaran. Siswa dapat aktif dalam kegiatan pembelajaran serta terfasilitasi untuk lebih memahami materi yang dipelajari. Data observasi terhadap kemampuan berpikir kritis tersebut semua menunjukkan peningkatan dibanding pada siklus I, dan telah melampaui indikator keberhasilan penelitian . tabel berikut :

Hasil belajar yang diperoleh pada pretest dan postest siklus II disajikan dalam Tabel 6: Data Hasil Belajar Siswa pada Siklus II

\begin{tabular}{|lcc|}
\hline \multicolumn{1}{|c|}{ Jenis test } & Pretest & Postest \\
\hline Nilai tertinggi & 80 & 90 \\
\hline Nilai terendah & 65 & 70 \\
\hline Rata-rata & 69 & 81 \\
\hline Jumlah siswa yang mencapai KKM & 10 & 24 \\
\hline
\end{tabular}

Dari tabel 6 diatas dapat diketahui bahwa jumlah peserta didik yang mendapatkan nilai lebih dari KKM adalah $77 \%$. Peningkatan nilai rata-rata dan jumlah siswa yang mencapa KKM menunjukkan peningkatan tingkat pemahaman siswa terhadap materi yang dipelajari.

Pembahasan umum pada siklus II, kegiatan guru dalam memberi informasi terkait materi cukup leluasa, hal ini didukung antusias siswa dalam mengikuti 
pembelajaran. Sebagian besar hal hal yang terkait materi dapat disampaikan pada pertemuan pertama, dan pada akhir pertemuan kedua guru menambahkan beberapa materi sebagai penguat atau pembetulan konsep konsep yang kurang lengkap. Kegiatan pembelajaran banyak diisi dengan diskusi atau menyelesaikan masalah yang telah diberikan guru, baik dari LKS maupun pertanyaan siswa lain dalam diskusi kelas. Siswa dapat saling melengkapi informasi terkait materi pelajaran yang sedang dibahas. Pada akhir siklus II guru bersama siswa menyusun kesimpulan sehingga persepsi dan ketercapaian materi telah terjadi kesamaan antara guru dengan siswa.

Aktifitas siswa selama pembelajaran berbasis masalah dapat diamati melalui keterlibatan siswa pada pembelajaran . Sebelum penerapan pembelajaran berbasis masalah keterlibatan siswa dalam proses pembelajaran sangat kurang. Pada saat diterapkan pembelajaran siklus I hasil observasi menunjukkan bahwa sebagian siswa telah dapat aktif terlibat langsung dalam pembelajaran, baik berupa perumusan masalah, mencari penyelesaiaan masalah , serta menjawab soal soal yang disampaikan guru maupun soal dalam diskusi. Beberapa siswa dapat aktif berdiskusi dalam kelompoknya, tetapi sebagian siswa yang lain masih belum mau terlibat. Karena baru sebagian siswa yang memahami tentang tahap tahap pembelajaran berbasis masalah, oleh karenanya sebelum pembelajaran siklus II dimulai kembali guru memberikan penjelasan tentang tahap tahap pembelajaran berbasis masalah dengan lebih detail, kegiatan dilaksanakan diluar jam tatap muka.

Hasil refleksi tindakan siklus II, antara lain 1) selama pembelajaran baik pertemuan pertama dan kedua siswa tampak antusias, baik dalam mengikuti penjelasan guru maupun mengerjakan tugas, 2) pada saat diskusi dimulai siswa sudah siap dengan jawabannya, hal ini sudah diketahui berdasar pengalaman pada siklus I, 3) pada saat diskusi, tampak banyak tanya jawab dan mengakibatkan pembelajaran tampak hidup, 4) akhir postest siklus II hasilnya mengalami peningkatan yang signifikan.

Pada pelaksanaan pembelajaran selama tindakan, kemampuan berpikir kritis tampak mengalami peningkatan seperti data pada tebel berikut:

Tabel 7. Data Hasil Observasi Kemampuan Berpikir Kritis Siklus I dan Siklus II

\begin{tabular}{|c|c|c|c|}
\hline No & Kemampuan berpikir kritis & $\begin{array}{c}\text { Persentase } \\
\text { siklus I }\end{array}$ & $\begin{array}{c}\text { Persentase } \\
\text { siklus II }\end{array}$ \\
\hline 1 & Mengidentifikasi masalah & $53 \%$ & $83 \%$ \\
\hline 2 & Menemukan penyebab peristiwa & $63 \%$ & $81 \%$ \\
\hline 3 & Menilai dampak peristiwa & $67 \%$ & $83 \%$ \\
\hline 4 & Memprediksikan dampak lanjut & $50 \%$ & $76 \%$ \\
\hline 5 & Merancang solusi penyelesaian masalah & $63 \%$ & $81 \%$ \\
\hline
\end{tabular}


Berdasar tabel 7 , kemampuan berpikir kritis siswa tampak mengalami perubahan yang sangat berarti pada akhir siklus II. Nilai tertinggi pada kemampuan berpikir kritis adalah kemampuan mengidentifikasi masalah dan kemampuan menilai dampak peristiwa yaitu sebesar $83 \%$, hal dapat diartikan bahwa sebagian besar siswa telah mampu memahami permasalahan yang disajikan dalam narasi atau siswa telah dapat merumuskan dengan baik permasalahan yang ada dilingkungannya. Persentase terendah adalah kemampuan memprediksikan dampak lanjut yaitu $76 \%$. Kemampuan memprediksikan sesuatu memang memerlukan tingkat berpikir lebih tinggi yaitu menganalisa hal hal yang dihadapi, dengan $76 \%$ siswa dapat memprediksikan dampak lanjut, maka hal hal negatif dari permasalahan yang dirumuskan dapat diminimalisir.

Perubahan persentase dari siklus I ke siklus II tersebut bersifat positif dimana pada setiap aspek meningkat, yang berarti kemampuan berpikir kritis dapat ditingkatkan memalui penerapan pembelajaran berbasis masalah. Data perubahan kemampuan berpikir kritis dari siklus I ke siklus II disajikan dalam grafik berikut :

Grafik 1. Data Kemampuan Berpikir Kritis Siklus I dan Siklus II

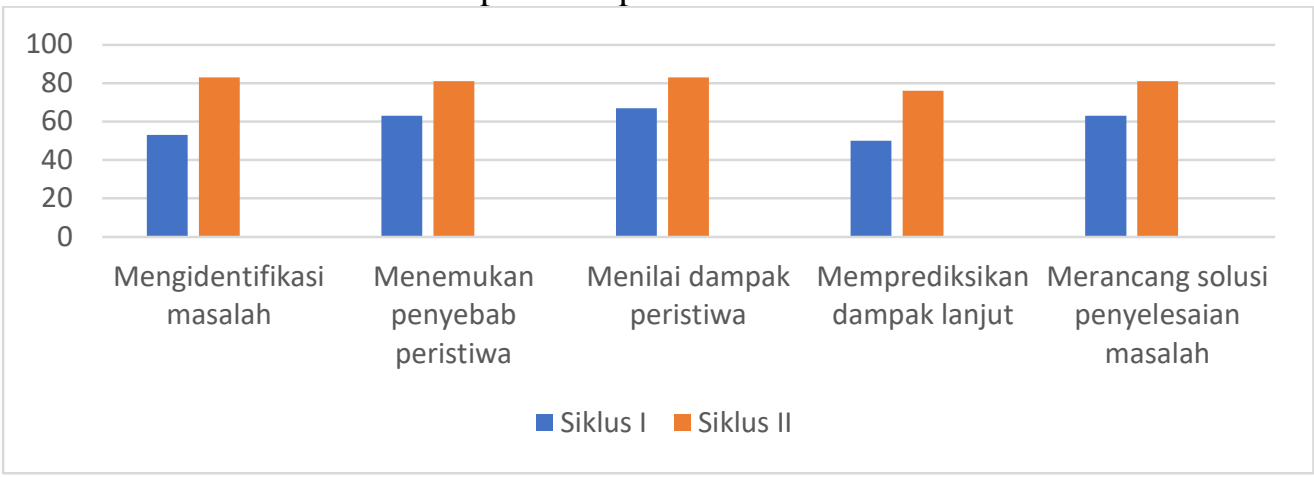

Hasil belajar pada siklus I dan II tampak mengalami perubahan yang sangat berarti, baik dilihat dari capaian nilai rata-rata maupun nilai tertinggi yang dapat diperolah siswa.

Tabel 8. Data Hasil Belajar Siklus I dan Siklus II

\begin{tabular}{|lccc|}
\hline \multicolumn{1}{|c}{ Jenis test } & $\begin{array}{c}\text { Sebelum } \\
\text { tindakan }\end{array}$ & $\begin{array}{c}\text { Postest } \\
\text { siklus I }\end{array}$ & $\begin{array}{c}\text { Postest } \\
\text { siklus II }\end{array}$ \\
\hline Nilai tertinggi & 85 & 85 & 90 \\
\hline Nilai terendah & 56 & 62 & 70 \\
\hline Rata-rata & 63 & 76 & 81 \\
\hline Jumlah siswa yang mencapai KKM & 6 & 14 & 24 \\
\hline
\end{tabular}


Pada data diatas dapat kita ketahui bahwa hasil belajar mengalami peningkatan yang berarti pada parameter yang digunakan. Dengan nilai rata-rata akhir siklus II adalah 81 berarti mengalami peningkatan 18 point dibanding siklus I. siswa yang telah mencapai KKM pada siklus II adalah 24 siswa dari 31 siswa yang berarti telah $77 \%$. Peningkatan jumlah siswa yang mencapai KKM sebanyak 18 siswa adalah suatu prestasi yang membanggakan, karena dapat mengurangi pendapat bahwa IPA adalah pelajaran yang sulit. Dengan data tersebut berarti indikator keberhasilan terlampaui yaitu $70 \%$ siswa dapat mencapai KKM.

Perubahan hasil belajar dari sebelum tindakan, siklus I dan II ditunjukkan pada grafik berikut:

Grafik 2 : Data Perubahan Hasil Belajar Sebelum Tindakan, Siklus I dan Siklus II

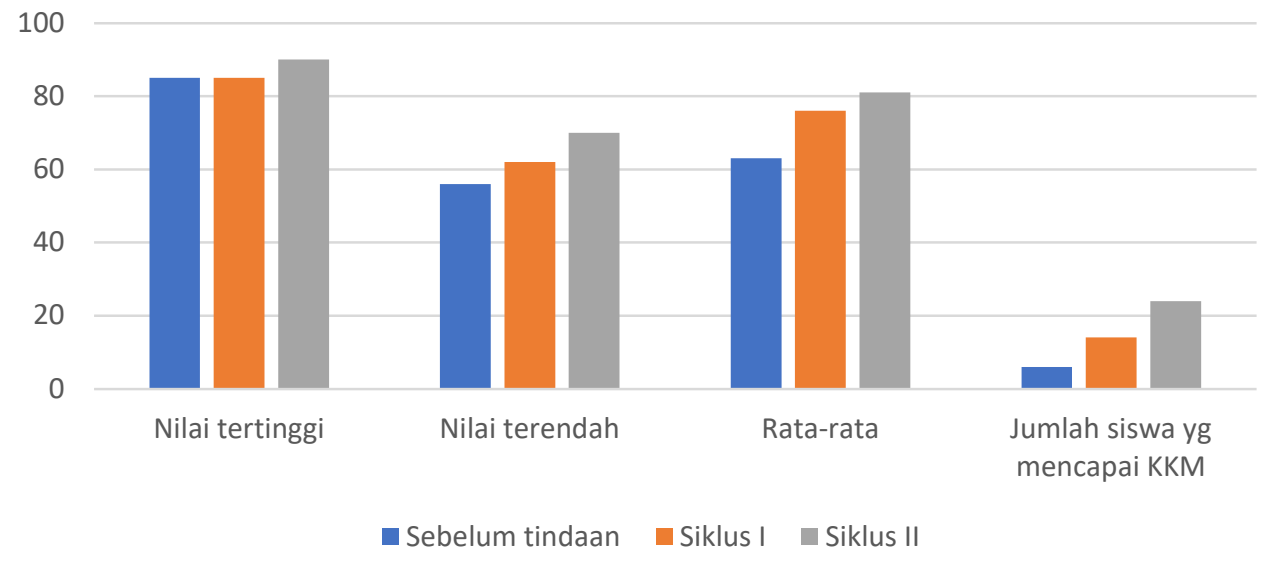

\section{KESIMPULAN}

Berdasarkan data hasil penelitian yang telah disampaikan pada hasil penelitian dan pembahasan dapat disimpulkan bahwa model Pembelajaran Berbasis Masalah dapat meningkatkan kemampuan berpikir kritis siswa hingga akhir siklus II mencapai jumlah melebihi atau sama dengan $76 \%$, yang meliputi mengidentifikasi masalah $83 \%$, menemukan penyebab peristiwa $81 \%$, menilai dampak peristiwa $81 \%$, memprediksikan dampak lanjut $76 \%$ dan merancang solusi penyelesaian masalah $81 \%$. Untuk hasil belajar mengalami peningkatan yang berarti dari pembelajaran sebelum tindakan hingga akhir siklus II, yaitu nilai rata-rata meningkat 18 point dari nilai 63 menjadi 81, dan jumlah siswa yang mencapai KKM meningkat 18 anak dari 6 menjadi 24 di akhir siklus II.

\section{DAFTAR PUSTAKA}

Arends, Richard I. 2008. Learning to Teach. Yogyakarta: Pustaka Pelajar Bowell, T.\& Kemp,G. (2002). Critical Thinking : a Concise guide. London :Routledge. Daniel Dike. 2008.Peningkatan Kemampuan Berpikir Kritis Siswa dengan Model TASC (Thingking Actively in a Social contex) pada Pembelajaran IPS SD. Tesis tidak diterbitkan. Yogyakarta:Program Pasca Sarjana UNY. 
Endah Puji Novisetyarini.2010. Peningkatan Kemampuan Berpikir Kritis melelui Metode Pembelajaran Problem Based learning pada pokok bahasan Ekosistem dn pencemaran Lingkungan Kelas X-8 Semester II SMAN 2 YogyakartavTahun Ajaran 2009/20010. Stripsi tidak diterbitkan. Yogyakarta:FMIPA UNY.

Nana Sudjana. 2009. Penilaian Hasil Belajar Meengajar. Bandung.Remaja Rosdakarya.

Suharsimi Arikunto, Suharjono,\&Supardi. 2008. Penelitian Tindakan Kelas. Jakarta:Bumi aksara.

Wina Sanjaya. 2008. Strategi Pembelajaran. Jakarta :Prenada Media Group 